\title{
Day hospital and psychosocial care center: Expanding the discussion of partial hospitalization in mental health
}

\author{
César Augusto Trinta Weber ${ }^{1 *}$, Mario Francisco Juruena ${ }^{2}$ \\ 1Post-Doctoral - Physician/Specialized in Health, Secretaria da Saúde do Estado do Rio Grande do Sul (SES/RS). Head Professor of Public Policies in Mental Health, Centro de Estudos José de Barros Falcão (CEJBF). \\ President of the Technical Chamber for Health Auditing, Conselho Regional de Medicina do Estado do Rio Grande do Sul (Cremers), Porto Alegre, RS, Brazil \\ 2Post-Doctoral - Coordinator of the Program for Assistance, Teaching and Research on Stress, Trauma and Mood Disorders (EsTraDA) and of the Psychiatric Day Hospital, Hospital das Clínicas, Faculdade de Medicina de \\ Ribeirão Preto, Universidade de São Paulo (HC-FMRP-USP), Ribeirão Preto, SP, Brazil
}

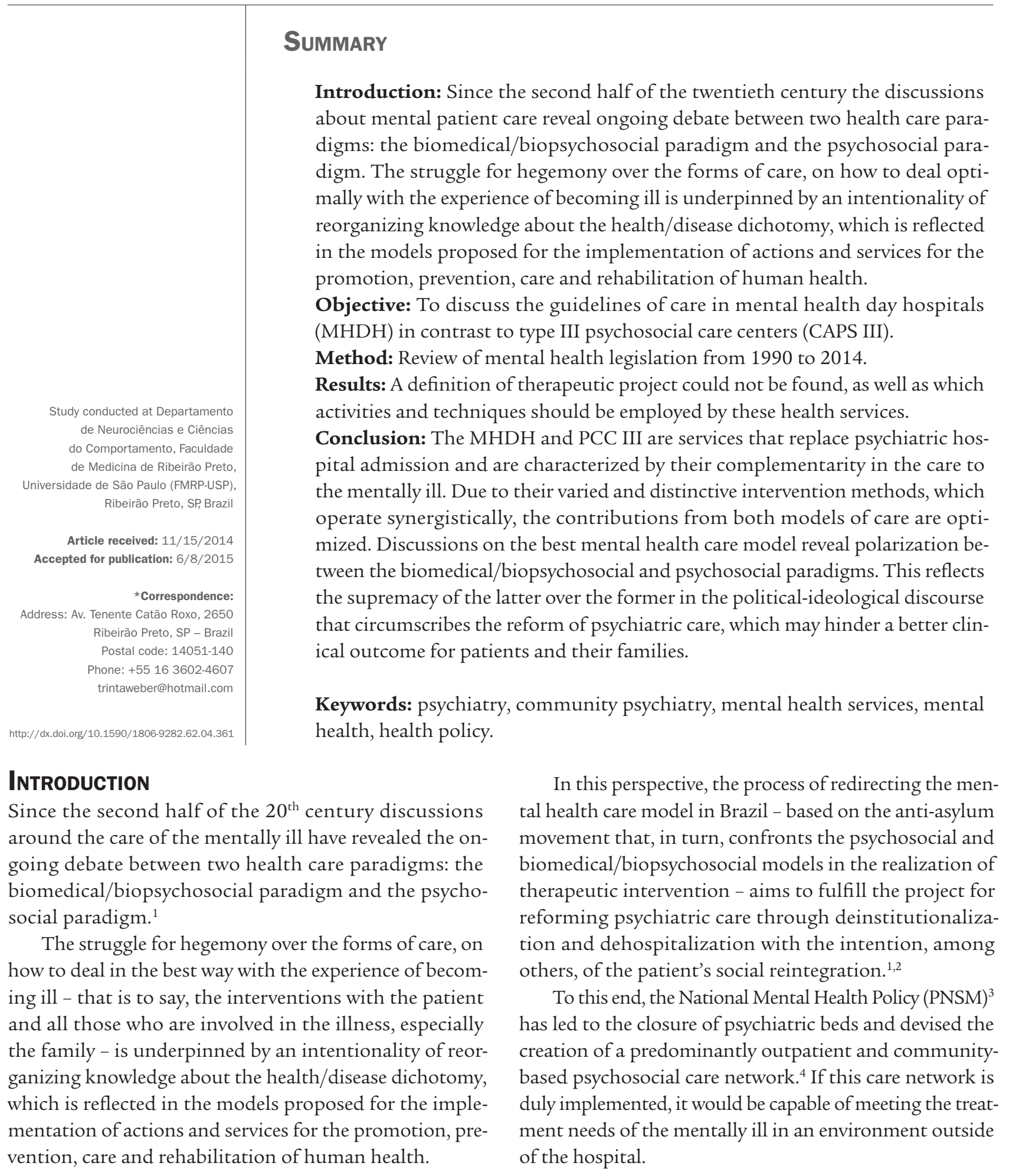


In this attempt at reorganization of care for the mentally ill, we can observe that the ideas circulating about the method of operating health facilities at outpatient level have led to polarization, at least in terms of theoretical exploration, between mental health day hospitals ( $\mathrm{MHDH})$ and psychosocial care centers (CAPS) ${ }^{1-3}$

In the ensuing discussion about the best model of care for the mentally ill, these two therapeutic modalities MHDH and CAPS - became icons in such a way that the first represents the biomedical/biopsychosocial model/ focus/paradigm, while the second is identified in connection with the psychosocial model/focus/paradigm. ${ }^{2}$

The systematized opinions surrounding the biolog$\mathrm{ical}$ /psychosocial dichotomy in public health policies, especially for mental health, proved to be conflicting and markedly ideological. ${ }^{1}$

The purpose of this article is to question the $\mathrm{MHDH}$ care guidelines and its place in the Brazilian National Mental Health Program (PNSM) in contrast to the CAPS III, both in the care to psychiatric patients and their family.

\section{Method}

This was a qualitative study using a documentary research technique. A review of the Brazilian legislation on mental health from 1990 to 2014.

\section{Results}

The guidelines for mental health care offered by the $\mathrm{MHDH}$ and CAPS III were reviewed in the Brazilian legal framework dealing with the protection and rights of people with mental disorders and the normative framework of the Brazilian public healthcare system (SUS, Unified Health System).

The national mental health policy and psychosocial care network Table 1 presents the main aspects of the redirecting of psychiatric care in Brazil. ${ }^{3}$ Table 2 presents the major components, both hospital and outpatient, that constitute the network of psychosocial care in the SUS. ${ }^{4}$

\section{TABLE 1 Main aspects of Law 10.216/01. ${ }^{3}$}

\begin{tabular}{l} 
Law $\mathbf{n}^{\circ} \mathbf{1 0 . 2 1 6 / 0 1}$ \\
\hline Rights for people with mental disorders \\
\hline Social reintegration of the patient in their environment \\
\hline Preferably community mental health services \\
\hline Hospitalization only if there are insufficient outpatient resources \\
\hline Admission scheme with full care \\
\hline Admission prohibited at institutions with asylum characteristics \\
\hline Institutionalization shall be treated by a specific policy \\
\hline Governs voluntary, involuntary and compulsory admission
\end{tabular}

TABLE 2 Psychosocial care network - MS/GM Ordinance $\mathrm{n}^{\circ} 3.088 / 01{ }^{4}$

MS/GM Ordinance $n^{\circ} 3.088 / 01$

psychosocial care network

\begin{tabular}{ll}
\hline Hospital component & Outpatient component \\
\hline Hospital emergency/ & Basic health unit \\
\cline { 2 - 2 } first aid doors & FHS (family health strategy) support center \\
\cline { 2 - 2 } & Street clinic \\
\hline Specialized ward at a & Convenience and culture center \\
\cline { 2 - 2 } general hospital & CAPS \\
\cline { 2 - 2 } & Emergency care unit \\
\hline Reference hospital & Therapeutic residential service \\
service & "Return home" program \\
\hline
\end{tabular}

\section{Mental health day hospital}

The MHDH has existed in Brazil since the 1960s. ${ }^{5,6} \mathrm{How}-$ ever, it was only officially included among the possibilities of mental health care in 1992. ${ }^{7}$

In order to meet, among other guidelines, the diversity of methods and techniques at various levels of health care complexity [emphasis added], the MS/MG Ordinance $n^{\circ} 224 / 927$ established detailed rules for hospital care in the SUS, with this level of health care complexity composed of the following health facilities: day hospitals (DH), psychiatric emergency services at general hospitals (emergency room), mental health wards at general hospitals and specialized psychiatric hospitals.

The mental health day hospital institution was defined as being an intermediate resource between hospitalization and outpatient care, providing intensive health care programs by multidisciplinary teams, aimed at replacing full hospitalization, and offering care to the patient, according to their individual needs, including the following activities: individual care (medication, psychotherapy, guidance, among others) [emphasis added]; group care (psychotherapy, task forces, therapeutic workshops, sociotherapy activities, among others); home visits; family care; community activities aimed at work integrating the mental health patient into the community and social inclusion. $^{7}$

MS/GM Ordinance n ${ }^{\circ}$ 147/948 amended MS/GM Ordinance $\mathrm{n}^{\circ} 224 / 927$, broadening the activities to be carried out by the $\mathrm{MHDH}$, especially with regard to the therapeutic project. a family approach including guidance about the diagnosis, the treatment program, discharge and continuation of treatment; preparation of the patient for hospital discharge, ensuring their preference for continuation of treatment at health unit with a care program compatible with their needs (outpatient, DH, psychoso- 
cial care service - NAPS/CAPS) in order to prevent the occurrence of further hospitalizations. These activities should constitute the therapeutic project of the institution, defined as the set of objectives and actions established and conducted by the multidisciplinary team, focused on the patient's recovery, from admission to discharge. This project must be presented in writing [emphasis added].

MS/GM Ordinance $n^{\circ} 44 / 019$ considering, among other requirements, the need to standardize care in the DH regime, established operational parameters for the entire national territory by approving, within the scope of the SUS, the DH care modality. It defines the conditions and specific requirements for providing care under the MHDH regime, including the provision of individual care (medication, psychotherapy, guidance, among others) [emphasis added].

\section{Psychosocial care center type III/CAPS III}

In order to meet, among other guidelines, the diversity of methods and techniques at various levels of health care complexity [emphasis added], MS/MG Ordinance ${ }^{\circ}$ 224/927 established the standards for hospital care in the SUS, with this level of health care complexity composed of the following health facilities: Basic Unit, Health Center, Outpatient Clinic, NAPS/CAPS. [a]

The NAPS/CAPS are local/regional health units, with a registered population defined at a local level, which offer intermediate care service between the outpatient and hospitalization schemes, during one or two four-hour shifts provided by a multidisciplinary team. ${ }^{7}$

GM/MS Ordinance $n^{\circ} 336 / 0210$ added new parameters to MS/GM Ordinance $n^{\circ} 224 / 927$ for the outpatient area, expanding the scope of services substituting daily care, establishing different sizes based on population criteria (CAPS I, II, III), as well as directing new services specific to the area of alcohol and other drugs, and childhood and adolescence.

The CAPS III is a psychosocial service with operational capacity to operate in cities with a population of over 200,000 inhabitants, characterized, among other things, by being linked to a general urgent/emergency care service within its region that provides the medical care support [emphasis added], and by providing service during the nighttime, public holidays and weekends, with a maximum of five beds for eventual rest and/or observation, among other individual care activities (medication, psychotherapy, guidance, and more) [emphasis added]. ${ }^{7,10}$

The Brazilian legislation and the norms of the SUS related to the NMHP did not include a definition of the therapeutic project or a detailed description of the activ- ities that should be performed both by the MHDH and the CAPS III, in accordance with their specificities and installed capacity, in the treatment of the mentally ill.

\section{Discussion}

The NMHP established in the country after the enactment of Law $\mathrm{n}^{\circ} 10.216 / 01,{ }^{3}$ seeks, in general terms, to reverse the health care model through strategies for increasing the quality of care, developing and stimulating alternative therapeutic practices to ensure full mental health care that is effective for psychosocial rehabilitation.

To form this "new model" of mental health care, the Ministry of Health adopted measures favoring the formation of a psychosocial care network, based on outpatient and community services, at the expense of hospitalization in psychiatric hospitals. In other words, the redirecting of the care model of the mentally ill has gone from one end of the scale to the other, from a previous hospital-centric model to clinical-centric model.

The position of the MHDH and the CAPS in the care of the mentally ill is defined by ordinances issued by the Ministry of Health and in accordance with the provisions of the NMHP. These are health facilities that act as therapeutic modalities on a mid-level of service between hospitalization and outpatient care. . $^{47-10}$

In this role of intermediate modalities - which are placed between full hospitalization and social life, the latter understood as outpatient monitoring of continued treatment, the CAPS occupies the central position between the substitute services that make up the psychosocial care network.

The CAPS is entrusted with performing the role of regulator of the care "gateway" within its territory, classified by different modalities defined in accordance with the population size/complexity/scope $\mathrm{e}^{10}$ and should take into account the cultural idiosyncrasies of each community where they are located, ${ }^{1,2}$ faced with the publicity of social inclusion of the mentally ill in their environment.

It may be accepted that, on the one hand, the place of these health facilities in the NMHP is a relatively undisputed subject. However, on the other hand, it is in the treatment plans of each of these services - especially due to the existing regulatory void - that we encounter the reasons for them being the springboards of a biased dispute, when compared to the scientific evidence, which is established in the discussion of the biomedical/biopsychosocial and psychosocial models of intervention, if translated into each of the actions which form part of these therapeutic plans.

It is worth highlighting the fact that by proposing the construction of a fresh look at madness and psycho- 
logical suffering, the Brazilian Reform has pointed toward the construction of new knowledge and new social practices, in a process similar to the production of knowledge from new paradigms about scientific truth, ${ }^{11}$ as can be observed among other guidelines that promotes the diversity of methods and techniques at various levels of mental health care complexity. ${ }^{7}$

However, we cannot ignore that the proposals of the DH and CAPS are quite heterogeneous, a fact that makes a precise conception of each of these activities difficult, as well as the identification of the elements differentiating one from the other. In the wake of this idea, another discussion arises that should not be ignored, which is one that reflects the possibility of these two therapeutic modalities being carried out by the same service, as is the case of the Rehabilitation Center and Day Hospital at the Institute of Psychiatry, Hospital das Clínicas, FMUSP. ${ }^{12}$

However, certain successful experiences in the suggested context should not, a priori, have the strength to induce the view that the managerial policy initiatives instituted for the replacement of the DH with the CAPS III are thereby justified and to be sustained as a tendency on their own, as has occurred in the past decade in Brazil. ${ }^{13}$

Two distinct and complementary care modalities, such as DH and CAPS III, can certainly be provided by a single service, however, this does not mean that this fact will make the specific activities of each one of them, that which differentiates them and thereby complements them, disappear. So, we should not speak of replacing one with another, but rather the conjunction of activities brought together in a single service, whose logical structuring can be summarized in the concept attributed to the Daily Care Service.

Daily Care Service was the term coined in 1995, during the $1^{\text {st }}$ Meeting of Daily Care Services in Rio de Janeiro, organized by the Institute of Psychiatry, the Pedro II Psychiatric Center, the Dr. Philipe Pinel Institute and the Uerj to designate all of the existing services in a new manner, and whose common aspect was serving a differentiated external clientele from both hospitals and the outpatient clinics, serving as substitute services to admission into psychiatric hospital.

Even though in the theoretical field we can observe several overlapping points between these two therapeutic modalities of psychiatric care, the DH service is directed mainly at the intensive treatment of illnesses (under the biopsychosocial approach, by a multiprofessional team), while rehabilitation is intended for people with impairments to their abilities, presenting major points of contact at the community level aimed at social reintegration. ${ }^{12}$
The two models, DH and CAPS, do not overlap, and we can assign two different assets to the DH: avoiding or shortening psychiatric hospitalizations, by possessing a more suitable environment for crises than CAPS (here, the DH would appear closer to the psychiatry wards), and implementing psychosocial rehabilitation actions and providing a greater capacity for more serious outpatient cases (where it is closer to outpatient services, such as CAPS). ${ }^{13}$

Lima and Botega warn of the fact that, in order to program changes in psychiatric care, we must be aware of the patients and the purpose of referring them to a $\mathrm{DH}$, as well as the factors that interfere in their adherence to treatment. ${ }^{14}$

Menezes and Mann call attention to the fact that when they are not hospitalized, many patients remain in their homes for months or years, with difficulties establishing contact with other people and adhering to outpatient treatments. ${ }^{15}$

We cannot lose sight of the fact that the choice of hospitalizing a patient for treatment, from a medical point of view, responds directly to the need required by the severity imposed by the illness and the resultant risks. Psychiatric intervention in a service of greater complexity, in this case, a hospital environment, ultimately seeks to stabilize the clinical symptoms presented by ensuring physical and moral integrity to the patient and others, among other aspects. In these cases the care required could not be performed in an outpatient service of this nature due to the fact that this would not have a compatible installed and decisive capacity, proving to be an insufficient level of care for the management of severe cases, for example.

The CAPS III has an installed and decisive capacity compatible with stable psychiatric clinical conditions in which care offered is geared towards social reintegration, to the extent that there is a need to be linked to a general urgent/emergency service in the region, which will provide medical care. ${ }^{10}$

The difference between a DH and any partial hospitalization method or intermediate structure for rehabilitation and social reintegration (sheltered housing, day centers, night hospitals, sheltered workshops, among more) lies in the fact that it is a resource that offers a therapeutic program that gives emphasis to the clinical and therapeutic manifestations and commits the patient and their family to a contractual therapeutic relationship with the therapy team, with active participation and implications.

The MHDH is a therapeutic resource which, by treating the patient for a limited time without the need of removal from their social, family, business or academic environ- 
ment, attempts to prevent the detention and marginalization/ exclusion and of the psychiatric patient.

In 1948, Bierer described how the day hospital in England was being used as a place where an attempt is made, as far as possible, to make all kinds of in-hospital treatment usable, along with the advantages enjoyed by patients out of hospital. ${ }^{16}$

The CAPS, as an intermediary between a hospital and a mental health clinic, is entrusted with caring for the chronically mentally ill and psychotic patients, most often after having left psychiatric hospital and in need of intensive out-of-hospital care. It serves a restricted gamut of patients per operating shift, as a type of health unit that provides care outside of the hospital, integrated with a decentralized mental health care network.

In this type of patient service, care of the patient is aimed at psychosocial rehabilitation (reintegration into the family, work, school, church and other segments of the community), with an emphasis on multidisciplinary teamwork and interdisciplinary and transdisciplinary actions.

The term Psychosocial Rehabilitation has been widely used to define a certain model of practices employed in the new substitute mental health services that have arisen in Brazil. The International Association of Psychosocial Rehabilitation Services helps to bring the classical definition of the term, which would be the process of facilitating the individual with limitations toward rehabilitation, at the best possible level of autonomy for exercising their functions in the community. The process emphasizes the healthier parts and the entire potential of the individual through a comprehensive approach and a vocational, residential, social, recreational and educational support, adapted to the unique demands of each individual and each situation in a personalized manner. ${ }^{17}$

Therefore, the service conducted at the $\mathrm{DH}$ and the service rendered by the CAPS III should not be confused. It is important to clarify that the regulation treats each one differently from the other. In the MHDH, treatment is within the context of hospitalization, whereas in the CAPS III care is provided through a reception service, including nighttime, public holidays and weekends, with a limitation on the number of beds for occasional rest and/or observation, as well as for permanence of the same patient. ${ }^{10}$

There is no doubt that the treatment of mental illness, even in the presence of a medical condition that requires hospitalization - whether in a general or psychiatric hospital - is an issue that is still open for discussion. ${ }^{1}$

Faced with this issue, Botega ${ }^{18}$ draws attention to the fact that this controversy has been marked by conflicting political and doctrinal stances, which makes the debate more complex than simple adherence to different technical options.

Health-related issues, especially illness and cure, which are understood as resulting from biological, psychological, social and cultural phenomena, are explained differently by the paradigms of the Biomedical Sciences and Social Sciences. ${ }^{19}$

On the one hand, there is a dissonance between these two paradigms both clinically and in terms of rehabilitation in the provision of care, giving the impression of the existence of a permanent divergence in the understanding of the phenomena that involve the illness, when acting in an individualized manner.

On the other, the biomedical paradigm has been shown to be insufficient for addressing the problem of mental illness in its entirety, and even more so for its method of caring for such illnesses, a fact that has led many health professionals interested in the social and cultural and, in some cases, even the spiritual dimensions involved in health, disease and healing processes., ${ }^{2,19}$

Integrative attempts to understand complex health issues can transcend the boundaries of disciplines and knowledge and provide opportunities to observe the phenomena from different perspectives. ${ }^{2}$

The Ministry of Health has reaffirmed the HumanizaSUS as a policy that runs through different actions and instances of the Unified Health System, encompassing different levels and dimensions of care and management. Operating on the principle of mainstreaming, the National Humanization Policy (NHP) uses tools and devices to consolidate networks, connections and shared responsibility between users, workers and managers. By targeting strategies and methods for coordinating actions, knowledge, practices and subjects, we can effectively enhance the guarantee of comprehensive, decisive and humanized care. ${ }^{20}$

Finally, as a contribution to the theoretical dispute that has been caught up between the applicability of one paradigm or another for mental health care, it can be inferred that in the face of scarce publication at both the official regulatory and academic scientific levels about the expanded clinical practice, therapeutic project and their respective activities, the visibility and exchange of ideas and experiences are hindered because they are limited, a fact that contributes to maintaining the discursive status of sterile outlines on the topic.

As a suggestion, follow-up studies of people with mental disorders who receive assistance and care at community-based outpatient mental health services, including Day Hospitals, CAPS, community groups and other therapeutic modalities that are part of the social support net- 
work should be encouraged for the monitoring and evaluation of the effects of these interventions on the quality of life of those going through the experience of the illness, with an emphasis on the inclusion of the mentally ill in their environment, given that it is known that the social reintegration of these patients demands, in the majority of cases, slow and prolonged work whose effects are best observed 12 to 24 months after discharge from treatment.

\section{Conclusion}

The field of mental health, especially from the end of the 1970s, has been marked by debate on changes to the mental health care model where discussions on how best to care for and rehabilitate these patients gained prominence and led to reformulation of psychiatric intervention practices. ${ }^{1}$

Indeed, the criticisms of the medical/biopsychosocial paradigm, among other aspects, related to the psychiatric diagnosis, are recognized as being so relevant that the contributions of applied social sciences, especially Medical Anthropology, or if preferred, Anthropology of Health, have been well accepted and incorporated.

It is known that a key problem of the diagnosis is the fact that the existing classification systems that have been elaborated are based solely on subjective descriptions of symptoms. This detailed phenomenology includes the description of multiple clinical subtypes. However, there is no biological characteristic that differentiates one subtype from another. Furthermore, it is recognized that a variety of disorders may display similar clinical symptoms, and that the same disorder may manifest itself differently in different people. ${ }^{2}$

The MHDH and CAPS III are services that replace psychiatric hospitalization ${ }^{1}$ and are characterized by their complementarity in the care of the mentally ill. It is precisely because of their varied and distinctive methods of intervention that these two models of care, operating in synergy, are enhanced by the contributions from one approach or the other.

Still, the discussions about the best model of mental health care, polarized between the biomedical/biopsychosocial and psychosocial paradigms, reflect the hegemony of the latter over the former in the political-ideological discourse that circumscribes the reform of psychiatric care, leaving the psychiatric medical aspects related to a better clinical outcome for the patient and all those involved with mental illness on a lower level.

That's without forgetting that the support of the family and the community in the care of the mental health patient is essential. On the one hand, there are family support therapies for understanding the phenomenon of the illness, demystifying the condition and its forms of treatment and, on the other, mechanisms for encouraging social support networks as forms of support in the perspective of a new look at mental health care.

As a result, we should highlight that the projects that seek social inclusion of the mentally ill have heterogeneous operating rationales and their effects are closely reliant on the cultural practices of the places where they are performed..$^{21}$

\section{Resumo}

Hospital-dia e Centro de Atenção Psicossocial: ampliando o debate da internação parcial em saúde mental

Introdução: desde a segunda metade do século $\mathrm{XX}$, as discussões em torno da assistência ao doente mental revelam o debate, ainda inacabado, entre dois paradigmas de atenção à saúde: o paradigma biomédico/biopsicossocial e o paradigma psicossocial. A luta pela hegemonia sobre as formas do cuidado, sobre a melhor maneira de lidar com a experiência do adoecimento, subjaz a uma intencionalidade de reorganização dos saberes sobre o binômio saúde/doença, que se reflete nos modelos propostos para a execução das ações e serviços de promoção, prevenção, assistência e reabilitação da saúde humana.

Objetivo: problematizar as diretrizes do cuidado do Hospital-dia em Saúde Mental (HDSM) em contraste com o Centro de Atenção Psicossocial tipo III (CAPS III).

Método: revisão da legislação em saúde mental entre 1990-2014.

Resultados: não foi encontradas a definição de projeto terapêutico e as atividades e técnicas que devem ser empregadas por esses serviços de saúde.

Conclusão: o HDSM e o CAPS III são serviços substitutivos à internação hospitalar psiquiátrica que se caracterizam pela complementaridade na atenção ao doente mental. Pelos seus variados e distintos métodos de intervenção, em ação sinérgica, potencializam-se com as contribuições tanto de um modelo quanto do outro modelo de atenção. As discussões em torno do melhor modelo de atenção em saúde mental mostram-se polarizadas entre os paradigmas biomédico/biopsicossocial e psicossocial, condição que reflete a supremacia do segundo sobre o primeiro no discurso político-ideológico que circunscreve a reforma da assistência psiquiátrica, fato que pode prejudicar o desfecho clínico para o paciente e sua família.

Palavras-chave: psiquiatria, psiquiatria comunitária, serviços de saúde mental, saúde mental, política de saúde. 


\section{References}

1. Weber CAT. Direction of mental health in Brazil after 1980. Revista Debates em Psiquiatria. 2013; 3(3):14-22.

2. Juruena MF, Marques AH, Mello AF, Mello MF. A paradigm for understanding and treating psychiatric illness. Rev Bras Psiquiatr. 2007; 29(suppl.1):s1-s2

3. Brasil. Lei n.10.216/01. Dispõe sobre a proteção e os direitos das pessoas portadoras de transtornos mentais e redireciona o modelo assistencial em saúde mental. Brasília: Diário Oficial da União, 2001

4. Brasil. MS. Portaria n. 3.088/01. Institui a Rede de Atenção Psicossocial para pessoas com sofrimento ou transtorno mental e com necessidades decorrentes do uso de crack, álcool e outras drogas, no âmbito do Sistema Único de Saúde. Brasília: Diário Oficial da União, 2001

5. Blaya M. O primeiro hospital-dia psiquiátrico no Brasil: análise do seu funcionamento e de seus problemas. Arq Clin Pinel. 1962; 1:28-33.

6. Campos MA. O hospital-dia como alternativa assistencial em psiquiatria: opinião de pacientes e seus familiares. [Thesis]. Ribeirão Preto: Universidade de São Paulo, 1986

7. Brasil. MS. Portaria n. 224/92. Estabelece as diretrizes e normas para o atendimento em saúde mental. Brasília: Diário Oficial da União, 1992.

8. Brasil. MS. Portaria n. 147/94. Estabelece melhoria da assistência às pessoas portadoras de transtornos mentais. Brasília: Diário Oficial da União, 1994.

9. Brasil. MS. Portaria n. 44/01. Aprova no âmbito do Sistema Único de Saúde a modalidade de assistência - Hospital Dia. Brasília: Diário Oficial da União, 2001.
10. Brasil. MS. Portaria n. 336/02. Estabelece CAPS I, CAPS II, CAPS III, CAPS i II e CAPS ad II. Brasília: Diário Oficial da União, 2002.

11. Yausi S. Rupturas e encontros: desafios da reforma psiquiátrica brasileira. [Thesis] Rio de Janeiro: Escola Nacional de Saúde Pública Sérgio Arouca, 2006.

12. Mateus MD. Fundamentos e prática em hospital-dia e reabilitação psicossocial. Rev Bras Psiquiatr. 2009; 31(1);83-3.

13. Bettarello SV, Greco F, Silva Filho FMA, Silva MCF. Fundamentos e prática em hospital-dia e reabilitação psicossocial. São Paulo: Atheneu, 2008.

14. Lima MCP, Botega, NJ. Hospital-dia: para quem e para quê? Rev Bras Psiquiatr. 2001; 23(4):195-9.

15. Menezes PR, Mann AH. The social adjustment of patients with schizophrenia: implications to the mental health policy in Brazil. Rev Saúde Pública. 1993; 27(5):340-9.

16. Furtado T. Hospital-dia, passageiro para a vida: o jogo da identidade e da diferença. Rio de Janeiro: Revinter, 1994.

17. Pitta AM. Qualidade de serviços de saúde mental: desafios para a epidemiologia. Jornal Brasileiro de Psiquiatria. 1996; 45(6):313-21.

18. Botega, NJ (ed.). Prática psiquiátrica em hospital geral: interconsulta e emergência. 3.ed. Porto Alegre: Artes Médicas, 2011.

19. Weber CAT. Mental health and culture: an anthropological perspective. Revista Debates em Psiquiatria. 2012; 2(4):16-22.

20. Brasil. MS. Clínica ampliada, equipe de referência e projeto terapêutico singular. 2.ed. Brasília: Ministério da Saúde, 2008.

21. Weber CAT. Mental health services: the challenge of social inclusion. Revista Debates em Psiquiatria. 2013; 3(1):26-35.

[a] Other health care provisions of the outpatient component were added to the psychosocial care network after publication of MS/GM Ordinance $n^{\circ} 3.088 / 01 .{ }^{4}$ However, as they do not hold a direct relationship with the MHDH and/or CAPS III they were not mentioned, without prejudice to the objective of this article. 